\title{
Uptake of hepatitis $B$ vaccination and its determinants among health care workers in a tertiary health facility in Enugu, South-East, Nigeria
}

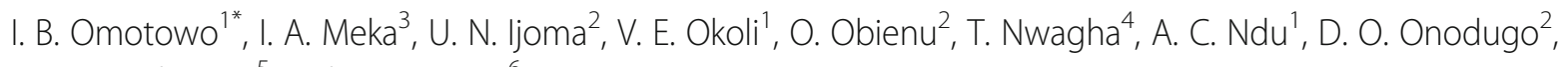
L. C. Onyekonwu ${ }^{5}$ and E. O. Ugwu ${ }^{6}$

\begin{abstract}
Background: Hepatitis B vaccination is the most effective method of prevention for hepatitis B virus infection. It is a major public health problem in Nigeria, and health workers are at increased risk. This study determined the uptake of hepatitis B vaccination and assessed its determinants among health care workers (HCWs).

Methods: A hospital-based cross-sectional study was conducted between July and August, 2016 using selfadministered structured questionnaires among 3132 HCWs in University of Nigeria Teaching Hospital, Enugu, South-East, Nigeria. Data was analysed using SPSS version 22. Binary logistic regression analysis was used to identify factors that influenced uptake of vaccination. Ethical clearance was obtained from the Research Ethics Committee of the health facility.

Results: The uptake of hepatitis B vaccination was 14.2\% $(n=445)$. The number of doses received were: 3 doses (218/3132, 48.9\%), 2 doses (71/3132, 16.0\%), and one dose (156/3132, 35.1\%). The reasons for non-uptake of vaccination included: cost of vaccine 48 (10.8\%), 'did not believe they could be infected' 28 (6.6\%), long vaccination schedule, and lack of time 150 (35.1\%). The Odds for uptake of hepatitis B vaccination were 22\% lower among nurses compared to doctors (AOR $=0.78,95 \% \mathrm{Cl}=0.54-0.98, P=0.037$ ). It increased with increasing age ( $\mathrm{AOR}=1.30,95 \% \mathrm{Cl}=1.08-1.59$, $P<0.001)$, increasing duration of work in the hospital $(A O R=1.19,95 \% \mathrm{Cl}=1.09-1.32, P=0.032)$, and was about twice higher among those that had tertiary education than others that had less education ( $A O R=1.96,95 \mathrm{Cl}=0.76-5.07$, $P=0.164)$.

Conclusions: The uptake of hepatitis B vaccination was low among HCWs in Enugu, Nigeria. Age, staff category, and duration of work in the hospital, were independently associated with hepatitis B vaccination. Provision of adequate hepatitis B surface antigen screening facilities and vaccination sites where the cost of vaccination is subsidized for all HCWs is recommended.
\end{abstract}

Keywords: Health care workers, Hepatitis B, Hepatitis B vaccine, Nigeria

\footnotetext{
* Correspondence: babatundeomotowo@yahoo.com

${ }^{1}$ Department of Community Medicine, College of Medicine, University of

Nigeria, Enugu Campus, Nigeria

Full list of author information is available at the end of the article
}

(c) The Author(s). 2018 Open Access This article is distributed under the terms of the Creative Commons Attribution 4.0 International License (http://creativecommons.org/licenses/by/4.0/), which permits unrestricted use, distribution, and reproduction in any medium, provided you give appropriate credit to the original author(s) and the source, provide a link to the Creative Commons license, and indicate if changes were made. The Creative Commons Public Domain Dedication waiver (http://creativecommons.org/publicdomain/zero/1.0/) applies to the data made available in this article, unless otherwise stated. 


\section{Background}

Hepatitis B is spread through contact with blood and body fluids of an infected person. It is a major public health problem in Nigeria and health care workers (HCWs) including general physicians, surgeons, dental surgeons, nurses and other medical staff. These HCWs are at increased risk of acquiring the disease due to occupational exposure to blood and body fluids [1, 2]. Hepatitis B is a life-threatening liver infection caused by Hepatitis B Virus (HBV). It can cause chronic and often fatal liver diseases, such as liver cirrhosis and cancer. Globally, about a billion individuals have been infected with HBV at some point in their lifetime and almost 350 million people are chronically infected with $\mathrm{HBV}$, out of which more than a million die annually from its related causes [3]. Majority of the infected cases are living in sub-Saharan Africa [4].

World Health Organization (WHO) reported that about two million health care workers risk occupational exposure to HBV each year and vaccination coverage is low among them [5]. The Department of Health and Human Services, Centers for Disease Control and Prevention (CDC) reported in United States that "the risk of being infected is dependent on the prevalence of the HBV carriers and frequency of exposure of HCWs to blood and body fluids and the infectivity of the virus" [6]. Health care workers in Nigeria are particularly at a greater risk because Nigeria is a holoendemic area, with HBV carrier rate of $15-37 \%$ [7]. The risk of acquiring $\mathrm{HBV}$ in some cadres of HCWs is four times greater than that of the general population [8].

Hepatitis B vaccination is the mainstay of HBV prevention and has been reported to reduce the risk of acquiring the infection virtually to zero $[9,10]$. It is recommended for exposed HCWs as part of the universal precautions policy for protection of HCWs [6]. HCWs who are HBV negative after screening should take hepatitis $B$ vaccination, while those who are HBV positive should be treated. However, vaccination among HCWs remains a challenge for many countries [11]. Some studies reported that all HCWs including administrative staff in a hospital can receive the hepatitis $B$ vaccine [11]. The mode of transmission of HBV in health care settings is most often by needle prick injuries and poor adherence to universal precautions [12]. The prevention of occupational hazards requires a thorough knowledge of the risks and practical measures to be taken, and the need for HCWs workers to familiarize themselves with universal work precautions [13]. It is estimated that about a million HCWs had cut and puncture injuries per year [14].

There is wide implementation of policy and uptake of the hepatitis $B$ vaccine in some countries such as UK, USA, and Israel [10]. In 2016, Nigeria developed a national guideline for prevention, care and treatment of
$\mathrm{HBV}$ and hepatitis $\mathrm{C}$ virus (HCV) infections, and vaccination of HCWs was included as one of the preventive methods in health care settings. However, to the best of the authors' knowledge, there is no policy or implementation of any policies that makes uptake of Hepatitis B vaccination compulsory to all HCWs in Nigeria. This study was conducted to evaluate the uptake of hepatitis $B$ vaccination and its determinants among HCWs in a tertiary health facility in South-East, Nigeria.

\section{Methods}

Study area

This study was conducted between July and August 2016 among HCWs in University of Nigeria Teaching Hospital (UNTH), Enugu, South-East Nigeria. The UNTH is a tertiary health facility, and the national cardiothoracic center of excellence. The facility attends to patients from all over Nigeria.

\section{Study design and sampling technique}

This was a hospital-based cross-sectional study. It was conducted prior to the free HBV and HCV screening programmes organised by Roche Products Limited in collaboration with the hospital's Management. To the best of the authors' knowledge, it was the first free HBV and $\mathrm{HCV}$ screening programme ever organized for all the hospital's HCWs.

\section{Data collection}

Data was collected using pre-tested self-administered structured questionnaires designed to collect information on socio-demographic characteristics, knowledge of transmission and risk factors of HBV, HBV status, uptake of hepatitis $B$ vaccination, doses of vaccine received, and reasons for non-uptake of the vaccine by the participants.

\section{Participants in the study}

Figure 1 shows the respondents' flow chart. The first stage showed that 3132 out of $3422 \mathrm{HCW}$ s completed the questionnaires correctly given a response rate of $91.2 \%$. In the second stage, $893(28.5 \%)$ out of 3132 knew their HBV status. Third stage showed that 872 (97.6\%) out of 893 participants that knew their HBV status were HBV negative, while 21 (2.4\%) were HBV positive. The fourth stage showed the participants who have received hepatitis $B$ vaccination and the doses received.

\section{Data analysis}

Data collected were analysed using SPSS version 22 (SPSS Inc., Chicago, Illinois, USA). Descriptive analyses were expressed as percentages. Socio-demographic characteristics of the respondents (age, sex, marital status, level of education, and duration of work in the hospital) 
- 3132 out of 3422 respondents participated in the study given response rate $91.5 \%$

First stage

$\checkmark$

- 893 (28.5\%) among 3132 participants knew their hepatitis B Status

- 872 (97.6\%) out of 893 participants had hepatitis B negative

- 21 (22.4\%) out of 893 were hepatitis B positive

$\sqrt{1}$

- 445 (51\%) among 872 participants took hepatitis B vaccination

- 156 (35.1\%) took 1 dose, 71 (16\%) took 2 doses, 218 (48.9\%) took 3 doses

Fig. 1 Participants flow chart

and how it affected the uptake of hepatitis B vaccination was determined. The relationship between the factors and uptake of hepatitis B vaccination was calculated using Chi-square test to determine significance at $p<0.05$. Binary logistic regression analysis was performed to determine socio-demographic characteristics of respondents associated with uptake of hepatitis $B$ vaccination and the number of doses received. Variables with statistical significance of $P \leq 0.2$ in the bivariate models were included in the multivariate analysis. Strength of association was expressed using Odds ratio and statistical significance presented using $P$-values and 95\% confidence intervals for odds ratio. For all analyses, P-values of $<0.05$ were considered statistically significant.

\section{Operational definitions}

Uptake of hepatitis B vaccination referred to respondents who have received at least one dose of the hepatitis $B$ vaccine. HBV negative referred to absence of hepatitis B surface antigen (HBsAg), while presence of HBsAg was referred as HBV positive. 'Knew their hepatitis B status' referred to respondents who have been screened in the past and had prior knowledge of their hepatitis B status, whether positive or negative. Full hepatitis $B$ vaccination referred to respondents who have received 3 doses of the vaccine.

\section{Ethical approval}

Ethical approval was obtained from Health Research Ethics Committee of the tertiary health facility, and informed written consent was obtained from all the participants.

\section{Results}

Socio-demographic characteristics of the participants The mean age of the participants was 39.4 \pm 9.6 (range: $18-75)$ years. Majority $1151(36.7 \%)$ were in the $31-$ 40 years age group. About three quarters 2237 (71.4\%) had tertiary education, 2174 (69.4\%) were married and $580(18.5 \%)$ were nurses. Majority of the participants 1938 (61.9\%) had worked for more than 5 years (Table 1 ).

\section{Knowledge on transmission of hepatitis B infection}

Table 2 shows that less than half of the participants knew that hepatitis B could be transmitted by needle prick, sharing of sharp objects, and sexual intercourse, while about $70 \%$ knew that blood transfusion was a mode of transmission. Only 3\% believed it could be transmitted by shaking of hands and $16.3 \%$ did not know any mode of transmission.

\section{Participants in the study flow chart and their uptake of hepatitis $B$ vaccination}

Table 3 shows the participants in each stage of the study. A total of 297 (9.5\%) doctors, 716 (22.9\%) nurses/pharmacists/lab workers, and 2119 (67.7\%) administrative staff were involved in the study. Participants who knew their HBsAg status were 893 (28.5\%). Twenty one, 21 (2.4\%) were $\mathrm{HBsAg}$ positive, while 872 (97.6\%) were $\mathrm{HBsAg}$ negative. Among the 872 participants who were $\mathrm{HBsAg}$ negative, 445 (51.0\%) have received at least one dose of hepatitis B vaccine while 427 (49.0\%) have not received any dose of hepatitis $B$ vaccine.

\section{Reasons for non-uptake of hepatitis B vaccine by the participants}

The reasons for non-uptake of hepatitis $B$ vaccination by the $427 \mathrm{HBsAg}$ negative participants included: cost of 
Table 1 Socio-demographic characteristics of the respondents $(N=3132)$

\begin{tabular}{|c|c|c|c|c|c|c|c|c|}
\hline \multirow{2}{*}{$\begin{array}{l}\text { Socio- } \\
\text { demographic } \\
\text { characteristics }\end{array}$} & \multicolumn{2}{|c|}{ Doctors ( $N=297)$} & \multicolumn{2}{|c|}{ Nurses/Pharmacists/Lab Workers $(N=716)$} & \multicolumn{2}{|c|}{ Admin staff $(N=2119)$} & \multicolumn{2}{|c|}{ Total $N=3132$} \\
\hline & $N$ & $\%$ & N & $\%$ & $N$ & $\%$ & N & $\%$ \\
\hline \multicolumn{9}{|l|}{ Sex } \\
\hline Male & 185 & 62.3 & 277 & 38.7 & 489 & 23.1 & 951 & 30.4 \\
\hline Female & 112 & 37.7 & 439 & 61.3 & 1630 & 76.9 & 2181 & 69.6 \\
\hline \multicolumn{9}{|c|}{ Age - group (Years) } \\
\hline$<20$ & 0 & 0 & 0 & 0 & 12 & 0.6 & 12 & 0.4 \\
\hline $20-30$ & 94 & 31.7 & 84 & 11.7 & 414 & 19.5 & 592 & 18.9 \\
\hline $31-40$ & 112 & 37.7 & 196 & 27.4 & 843 & 39.8 & 1151 & 36.7 \\
\hline $41-50$ & 66 & 22.2 & 298 & 41.6 & 558 & 26.3 & 922 & 29.5 \\
\hline $51-60$ & 21 & 7.1 & 138 & 19.3 & 273 & 12.9 & 432 & 13.8 \\
\hline$>60$ & 4 & 1.3 & 0 & 0 & 19 & 0.9 & 23 & 0.7 \\
\hline \multicolumn{9}{|l|}{ Education Level } \\
\hline Primary & 0 & 0 & 0 & 0 & 269 & 12.7 & 269 & 8.6 \\
\hline Secondary & 0 & 0 & 23 & 3.2 & 603 & 28.5 & 626 & 20.0 \\
\hline Tertiary & 297 & 100 & 693 & 96.8 & 1247 & 58.8 & 2237 & 71.4 \\
\hline \multicolumn{9}{|l|}{ Marital status } \\
\hline Married & 198 & 66.7 & 510 & 71.2 & 1466 & 69.2 & 2174 & 69.4 \\
\hline Single & 97 & 32.6 & 201 & 28.1 & 571 & 26.9 & 869 & 27.7 \\
\hline Separated & 0 & 0 & 0 & 0 & 11 & 0.5 & 11 & 0.4 \\
\hline Widowed & 2 & 0.7 & 5 & 0.7 & 71 & 3.4 & 78 & 2.5 \\
\hline \multicolumn{9}{|c|}{ Duration of work (Years of experience) } \\
\hline$<1$ Year & 38 & 12.8 & 19 & 2.7 & 206 & 9.7 & 263 & 8.3 \\
\hline $1-5$ Years & 152 & 51.2 & 101 & 14.1 & 678 & 32.0 & 931 & 29.8 \\
\hline$>5-10$ Years & 50 & 16.8 & 380 & 53.1 & 410 & 19.3 & 840 & 26.8 \\
\hline$>10$ Years & 57 & 19.2 & 216 & 30.1 & 825 & 39.0 & 1098 & 35.1 \\
\hline
\end{tabular}

the vaccine $(46 / 427,10.8 \%)$, didn't know where to receive the vaccine $(203 / 427,47.5 \%)$, didn't believe they could be infected $(28 / 427,6.6 \%)$, and other reasons including the long vaccination schedule of the vaccine and lack of time $(150 / 427,35.1 \%)$. Details are as shown in Table 4.

Factors associated with uptake of hepatitis B vaccination among participants that were hepatitis $B$ negative

Table 5 shows factors associated with uptake of hepatitis $B$ vaccination by the participants. After adjusting for age, sex, marital status, level of education, and professional categories, the Odds for uptake of hepatitis B vaccination were higher among single/separated/widowed participants compared to those that were married (AOR $=1.38,95 \% \mathrm{CI}=1.01-1.92, P=0.050)$. The Odds for uptake of hepatitis B vaccination were $22 \%$ lower among nurses compared to doctors $(\mathrm{AOR}=0.78,95 \% \mathrm{CI}=$ 0.54-0.98, $P=0.037$ ), while the Odds for the uptake of hepatitis $\mathrm{B}$ vaccination increased with increasing age $(\mathrm{AOR}=1.30,95 \% \mathrm{CI}=1.08-1.59, P<0.001)$. The Odds for uptake of hepatitis B vaccination also increased with increasing duration of work in the hospital (AOR $=1.19$, 95\% CI $=1.09-1.32, P=0.032$ ). It was about 2.1 higher among participants who had secondary education compared with those that had primary education $(\mathrm{AOR}=2.06,95 \% \mathrm{CI}$ $=0.75-5.61, P=0.159$ ), and about twice higher among those that had tertiary education than others that had less education $(\mathrm{AOR}=1.96,95 \mathrm{CI}=0.76-5.07, P=0.164)$.

\section{Discussion}

This study showed that the uptake of hepatitis B vaccination among HCWs in Enugu, Nigeria was poor. This is similar to the study conducted in Pakistan [15], but differs from other studies from India and Ethiopia [16, 17]. The authors found that $28.5 \%$ of the participants knew their hepatitis B status, and that $2.4 \%$ were hepatitis B positive, while $97.6 \%$ were hepatitis $\mathrm{B}$ negative. The observed low knowledge of hepatitis B status (28.5\%) in this study could be due to absence of pre-employment screening for hepatitis B as well as lack of policy concerning hepatitis B screening in the facility. It also 
Table 2 Knowledge on transmission of hepatitis B $(N=3132)$

\begin{tabular}{|c|c|c|c|c|c|c|c|c|}
\hline \multirow{2}{*}{$\begin{array}{l}\text { Transmitted } \\
\text { by: }\end{array}$} & \multicolumn{2}{|c|}{ Doctors $(N=297)$} & \multicolumn{2}{|c|}{ Nurses/Pharmacists/Lab Workers $(N=716)$} & \multicolumn{2}{|c|}{ Admin staff $(N=2119)$} & \multicolumn{2}{|c|}{ Total $N=3132)$} \\
\hline & $N$ & $\%$ & $N$ & $\%$ & $N$ & $\%$ & N & $\%$ \\
\hline \multicolumn{9}{|c|}{ Shaking of hands } \\
\hline Yes & 11 & 3.7 & 24 & 3.4 & 49 & 2.3 & 84 & 2.7 \\
\hline No & 286 & 96.3 & 692 & 96.6 & 2070 & 97.7 & 3048 & 97.3 \\
\hline \multicolumn{9}{|l|}{ Needle prick } \\
\hline Yes & 280 & 94.3 & 293 & 40.9 & 749 & 35.3 & 1322 & 42.2 \\
\hline No & 17 & 5.7 & 423 & 59.1 & 1370 & 64.7 & 1810 & 57.8 \\
\hline \multicolumn{9}{|c|}{ Blood transfusion } \\
\hline Yes & 284 & 95.6 & 614 & 85.8 & 1282 & 60.5 & 2180 & 69.6 \\
\hline No & 13 & 4.4 & 102 & 14.2 & 837 & 39.5 & 952 & 30.4 \\
\hline \multicolumn{9}{|l|}{ Heat } \\
\hline Yes & 12 & 4.0 & 57 & 8.0 & 140 & 6.6 & 209 & 6.7 \\
\hline No & 285 & 96.0 & 659 & 92.0 & 1979 & 93.4 & 2923 & 93.3 \\
\hline \multicolumn{9}{|c|}{ Sexual intercourse } \\
\hline Yes & 249 & 83.8 & 524 & 73.2 & 759 & 0.4 & 1532 & 48.9 \\
\hline No & 48 & 16.2 & 192 & 26.8 & 1360 & 99.6 & 1597 & 41.9 \\
\hline \multicolumn{9}{|c|}{ Drinking contaminated water } \\
\hline Yes & 49 & 16.5 & 105 & 14.7 & 232 & 10.9 & 386 & 12.3 \\
\hline No & 248 & 83.5 & 611 & 85.3 & 1887 & 89.1 & 2746 & 87.7 \\
\hline \multicolumn{9}{|c|}{ Contamination from surfaces } \\
\hline Yes & 81 & 27.3 & 89 & 12.4 & 402 & 18.9 & 572 & 18.3 \\
\hline No & 216 & 72.7 & 627 & 87.6 & 1717 & 81.1 & 2560 & 81.7 \\
\hline \multicolumn{9}{|c|}{ Sharing of sharp objects } \\
\hline Yes & 258 & 86.9 & 204 & 28.5 & 1027 & 48.5 & 1489 & 47.5 \\
\hline No & 39 & 13.1 & 512 & 71.5 & 1092 & 51.5 & 1643 & 52.5 \\
\hline \multicolumn{9}{|l|}{ Don't know } \\
\hline Yes & 0 & 0 & 26 & 3.6 & 486 & 22.9 & 512 & 16.3 \\
\hline No & 297 & 100 & 690 & 96.4 & 1633 & 77.1 & 2620 & 83.7 \\
\hline
\end{tabular}

suggests that the facility has not been regularly conducting free or subsidized screening for its HCWs. While it is expected that all individuals who are hepatitis B negative should take the vaccination, while those who are hepatitis B positive receive treatment, the study found that only $51 \%$ of participants who are hepatitis B negative have received hepatitis $B$ vaccination.

The overall uptake of hepatitis $B$ vaccination among HCWs in this study was $14.2 \%$. This is similar to what was observed in previous studies $[18,19]$. However, it is lower than $22.4 \%$ reported in the similar study in 2006 [20], and also among HCWs in a teaching hospital in Ile-Ife, South-West Nigeria which revealed that $65 \%$ of the health workers have been vaccinated against hepatitis B virus [4]. The observed uptake in this study is also lower than $54.8 \%$ reported among theatre and laboratory workers at a teaching hospital in Imo state, Nigeria [21].
These differences could be due to the fact that the current study involved a larger population, and also administrative staff which were not involved in previous studies. This study also revealed that only $28.5 \%$ of the participants had prior knowledge of their hepatitis B status. This poor result could be due to the cost of screening for hepatitis B surface antigen and its poor accessibility in Nigeria. Regular free or subsidized screening programmes might bring improvement in this regard.

It was observed that a higher proportion of administrative staff have not received hepatitis B vaccination compared to nurses, doctors, pharmacists and laboratory technologists. This higher uptake of hepatitis B vaccination among the clinical than administrative staff could be as a result of their pre-employment training and education which might have included the importance and safety of 
Table 3 Participants in the study flow chart $(N=3132)$

\begin{tabular}{|c|c|c|c|c|c|c|c|c|}
\hline \multirow[t]{2}{*}{ Variable: } & \multicolumn{2}{|c|}{ Doctors $(N=297)$} & \multicolumn{2}{|c|}{$\begin{array}{l}\text { Nurses/Pharmacists/Lab } \\
\text { workers }(N=716)\end{array}$} & \multicolumn{2}{|c|}{ Admin staff $(N=2119)$} & \multicolumn{2}{|c|}{ Total $(N=3132)$} \\
\hline & N & $\%$ & N & $\%$ & N & $\%$ & N & $\%$ \\
\hline \multicolumn{9}{|l|}{ Participants who knew their HBsAg status: } \\
\hline Yes & 162 & 54.6 & 282 & 39.4 & 449 & 21.2 & 893 & 28.5 \\
\hline No & 135 & 45.4 & 434 & 60.6 & 1670 & 78.8 & 2239 & 71.5 \\
\hline Total participants & 297 & 100.0 & 716 & 100.0 & 2119 & 100.0 & 3132 & 100.0 \\
\hline \multicolumn{9}{|l|}{ HBsAg of participants who knew their status: } \\
\hline HBsAg Positive & 1 & 0.6 & 6 & 2.1 & 14 & 3.3 & 21 & 2.4 \\
\hline HBsAg Negative & 161 & 99.4 & 276 & 97.9 & 435 & 96.7 & 872 & 97.6 \\
\hline Total who knew their status & 162 & 100.0 & 282 & 100.0 & 449 & 100.0 & 893 & 100.0 \\
\hline \multicolumn{9}{|c|}{ Participants who were HBsAg negative, and took/ did not take any dose of hepatitis B vaccine: } \\
\hline Took at least a dose & 98 & 60.9 & 155 & 56.2 & 192 & 44.1 & 445 & 51.0 \\
\hline Did not take any dose & 63 & 39.1 & 121 & 43.8 & 243 & 55.9 & 427 & 49.0 \\
\hline Total who were HBsAg negative & 161 & 100.0 & 276 & 100.0 & 435 & 100.0 & 872 & 100.0 \\
\hline \multicolumn{9}{|l|}{ Doses of vaccine taken by the participants: } \\
\hline $\begin{array}{l}\text { Participants who were HBsAg negative, and took } \\
\text { one dose }\end{array}$ & 8 & 8.2 & 26 & 16.8 & 122 & 63.5 & 156 & 35.1 \\
\hline $\begin{array}{l}\text { Participants who were HBsAg negative, and took } \\
\text { two doses }\end{array}$ & 16 & 16.4 & 44 & 28.4 & 11 & 5.8 & 71 & 16.0 \\
\hline $\begin{array}{l}\text { Participants who were HBsAg negative, and took } \\
\text { three doses }\end{array}$ & 74 & 75.4 & 85 & 54.8 & 59 & 30.7 & 218 & 48.9 \\
\hline Total who took at least a dose & 98 & 100.0 & 155 & 100.0 & 192 & 100.0 & 445 & 100.0 \\
\hline
\end{tabular}

vaccination to health. The management of health facilities should pay attention to administrative cadre of staff for improved uptake of hepatitis $B$ vaccination among its HCWs. Similarly, the duration of HCWs that had worked in the facility also influenced the uptake of hepatitis B vaccination. Higher proportion of those who had worked for more than 5 years in the facility received hepatitis B vaccination than those who had worked for less. This result could be due to lack of policy concerning hepatitis B vaccination of workers in the hospital. Also higher proportion of participants older than 30 years of age received hepatitis $B$ vaccination than those below 30 years old. This higher uptake of hepatitis B vaccination among older HCWs who are also more likely to have worked for longer

Table 4 Reasons for non-uptake of Hepatitis B vaccine by the Participants ( $N=427$ )

\begin{tabular}{|c|c|c|c|c|c|c|c|c|}
\hline \multirow[t]{2}{*}{ Reasons: } & \multicolumn{2}{|c|}{ Doctors $(N=63)$} & \multicolumn{2}{|c|}{ Nurses/Pharmacists/Lab Workers $(N=121)$} & \multicolumn{2}{|c|}{ Admin staff $(N=243)$} & \multicolumn{2}{|c|}{ Total $(N=427)$} \\
\hline & N & $\%$ & $N$ & $\%$ & $N$ & $\%$ & $N$ & $\%$ \\
\hline \multicolumn{9}{|l|}{ Cost } \\
\hline Yes & 4 & 6.3 & 7 & 5.8 & 35 & 14.4 & 46 & 10.8 \\
\hline No & 59 & 93.7 & 114 & 95.2 & 208 & 85.6 & 381 & 89.2 \\
\hline \multicolumn{9}{|c|}{ Don't know where to take the vaccine } \\
\hline Yes & 34 & 54.0 & 35 & 28.9 & 134 & 55.1 & 203 & 47.5 \\
\hline No & 29 & 46.0 & 86 & 71.1 & 109 & 45.9 & 224 & 52.5 \\
\hline \multicolumn{9}{|c|}{ Don't believe I could be infected } \\
\hline Yes & 1 & 1.6 & 3 & 2.5 & 24 & 9.8 & 28 & 6.6 \\
\hline No & 62 & 98.4 & 118 & 97.5 & 219 & 90.2 & 399 & 93.4 \\
\hline \multicolumn{9}{|c|}{ Others e.g. long vaccination schedule and lack of time } \\
\hline Yes & 3 & 4.8 & 19 & 15.7 & 128 & 52.7 & 150 & 35.1 \\
\hline No & 60 & 95.2 & 102 & 84.3 & 115 & 47.3 & 277 & 64.9 \\
\hline
\end{tabular}


Table 5 Factors associated with Uptake of Hepatitis B Vaccination among participants that had Hepatitis B Negative ( $N=872$ )

\begin{tabular}{|c|c|c|c|c|c|c|c|c|}
\hline \multirow[t]{2}{*}{ Variable: } & \multicolumn{4}{|c|}{ Uptake of Hepatitis B Vaccination $(N=872)$} & \multirow{2}{*}{$\begin{array}{l}\text { Chi-square } \\
\left(X^{2}\right)\end{array}$} & \multirow[t]{2}{*}{$P$ value } & \multirow[t]{2}{*}{ AOR $(95 \% \mathrm{Cl})$} & \multirow[t]{2}{*}{$P$ value } \\
\hline & Yes & $\%$ & No & $\%$ & & & & \\
\hline \multicolumn{9}{|l|}{ Sex } \\
\hline Male & 124 & 27.9 & 135 & 31.6 & 0.558 & 0.455 & 1.00 & \\
\hline Female & 321 & 72.1 & 292 & 68.4 & & & $0.93(0.69-1.24)$ & 0.305 \\
\hline \multicolumn{9}{|l|}{ Age group (Years) } \\
\hline$<30$ & 60 & 13.5 & 80 & 18.7 & 14.048 & 0.003 & 1.00 & \\
\hline $31-40$ & 187 & 42.0 & 191 & 44.7 & & & $1.30(1.08-1.59)$ & $<0.001$ \\
\hline $41-50$ & 126 & 28.3 & 117 & 27.4 & & & $1.38(1.09-1.65)$ & $<0.001$ \\
\hline $51-60$ & 7216.2 & & 39 & 9.2 & & & $1.41(1.12-1.73)$ & 0.032 \\
\hline \multicolumn{9}{|l|}{ Marital status } \\
\hline Married & 327 & 73.5 & 293 & 68.6 & 1.981 & 0.576 & 1.00 & \\
\hline Single/Separated/Widowed & 118 & 26.5 & 134 & 31.4 & & & $1.38(1.01-1.92)$ & 0.050 \\
\hline \multicolumn{9}{|l|}{ Education level } \\
\hline Primary & 8 & 1.8 & 13 & 3.0 & 1.825 & 0.768 & 1.00 & \\
\hline Secondary & 58 & 13.0 & 56 & 13.2 & & & $2.06(0.75-5.61)$ & 0.159 \\
\hline Tertiary & 379 & 85.2 & 358 & 83.8 & & & $1.96(0.76-5.07)$ & 0.164 \\
\hline \multicolumn{9}{|l|}{ Professional Categories } \\
\hline Doctors & 98 & 22.0 & 63 & 14.7 & 11.108 & 0.049 & 1.00 & \\
\hline Nurses/Pharmacists/Lab workers & 155 & 34.8 & 121 & 28.4 & & & $0.78(0.54-0.98)$ & 0.037 \\
\hline Admin staff & 192 & 43.2 & 243 & 56.9 & & & $0.23(2.67-5.69)$ & 0.241 \\
\hline \multicolumn{9}{|l|}{ Duration of work in the hospital } \\
\hline$<1$ Year & 33 & 7.4 & 124 & 29.0 & 18.742 & $<0.001$ & 1.00 & \\
\hline 1-5 Years & 109 & 24.5 & 95 & 22.3 & & & $1.19(1.09-1.32)$ & 0.032 \\
\hline$>5-10$ Years & 128 & 28.8 & 93 & 21.8 & & & $1.26(1.08-1.45)$ & 0.043 \\
\hline > 10 Years & 175 & 39.3 & 115 & 26.9 & & & $1.28(1.12-1.49)$ & 0.042 \\
\hline
\end{tabular}

AOR Adjusted Odds Ratio, 95\% Cl 95\% Confidence Interval, Reference category 1, $\mathrm{X}^{2}=$ Chi-square

duration might be due to their previous observations. It is possible they might have observed their colleagues suffer fulminant hepatitis and/or liver cancer as a result of possible non-uptake of hepatitis B vaccination. The reason for this higher uptake among this category of HCWs may also be due to previous hepatitis B vaccination related encouragements from colleagues. Such encouragement could lead to increase in awareness and knowledge of importance of screening and uptake of hepatitis B vaccination for those who are hepatitis B negative, and treatment for those who are hepatitis B positive. Formulation of policies to make screening for hepatitis B surface antigen and uptake of hepatitis $\mathrm{B}$ vaccination compulsory and at free or subsidized cost for all HCWs may bring improvement in uptake of hepatitis B vaccine.

This study found that $48.9 \%$ of those who were vaccinated had full coverage of the three doses of the vaccine, while 16 and $35.1 \%$ took two or one dose respectively. This is similar to the study conducted in Tanzania, and
India among HCWs where 48.8 and $50 \%$ received three doses of the vaccine respectively $[22,23]$. It is also similar to the study conducted among doctors and nurses in Lagos, Nigeria where $48.5 \%$ completed three doses of hepatitis B vaccination [24]. It is however lower than results documented in the study conducted among doctors and nurses in Iran which reported that $86.2 \%$ completed the recommended three doses of vaccine [25]. This difference might be due to the fact that the present study involved all health workers including administrative staff compared to study from Iran where only doctors and nurses were included. Thus, the differences in this study compared with other studies could be due to the inclusion of administrative staff, and the larger sample size. Interestingly, those who received three doses of vaccine in the current study is higher than the findings in other studies conducted in Nigeria, Sweden, Pakistan, and South Africa which reported 16.3, 29.7, 39.8, 37.2, and $19.9 \%$ respectively $[20,21,26-28]$. However, it is lower 
than the findings in a study done in Ethiopia where $61.2 \%$ of those vaccinated had received all 3 doses of the vaccine [17].

Our study revealed that age, staff category and duration of work in the facility significantly influenced uptake of hepatitis $B$ vaccination, but no factor significantly influenced full vaccination status. However, after adjusting for confounders, the odds for full hepatitis $B$ vaccination were higher among female participants than males $(\mathrm{AOR}=$ 1.17, $95 \% \mathrm{CI}=0.76-1.78, \quad P=0.265)$, tertiary education compared to primary education $(\mathrm{AOR}=2.94,95 \% \mathrm{CI}=$ 0.64-12.43, $P=0.328$ ), and among participants with longer duration of work $(\mathrm{AOR}=1.23,95 \% \mathrm{CI}=0.96-1.59$, $P=0.106$ ). These observations are similar to findings from some other studies which reported that sex, years of occupational practice, and educational status significantly influenced vaccination pattern $[4,20,21]$.

The findings in the current study showed that $10.8 \%$ of the participants did not receive hepatitis $B$ vaccination because of cost of vaccination, $47.5 \%$ did not know where to take the vaccination, $6.6 \%$ believed they could not be infected, while $51.1 \%$ gave other reasons such as long vaccination schedule, and lack of time. These findings are similar to a study conducted to find reasons for non-uptake of vaccine which reported inadequate vaccine information as a factor [11] and unavailability of vaccine and high cost of vaccine as major determinants [29]. The prevalence of HBV markers which includes individuals with $\mathrm{HBs} A g$, anti-HBc, and anti-HBs who do not need hepatitis B vaccination is $72.5 \%$ in Nigeria [30]. Recommendations from American College of Physicians and the Centers for Disease Control and Prevention is that screening for HBV should include testing to three HBV screening sero-markers so that persons can be classified into the appropriate hepatitis B category and properly recommended to receive vaccination, counselling, and linkage to care and treatment [31]. However in Nigeria, accessibility and cost of hepatitis B serological tests for HBV markers is a great challenge. The authors' opinion is that all HCWs should be screened for only HBsAg, and those that are negative should receive hepatitis $B$ vaccination to reduce the cost and other challenges.

\section{Conclusions}

This study revealed that uptake of hepatitis B vaccination as well as number of doses received was low among HCWs in Enugu, Nigeria. Age, staff category, and duration of work in the hospital, were independently associated with hepatitis B vaccination. It is therefore recommended that Management of health facilities in Nigeria should provide hepatitis B surface antigen screening facilities and hepatitis B vaccination sites for easy accessibility, and also subsidize the cost of screening for hepatitis B surface antigen and hepatitis B vaccination for all HCWs. They should also formulate policies that make screening for hepatitis B surface antigen and uptake of hepatitis $B$ vaccination for hepatitis $B$ negative HCWs compulsory and at free or subsidized cost. If possible, the Management should also frequently organize free screening for HBV for all its HCWs. This would increase the proportion of HCWs that know their hepatitis B status, as well as stimulate those that are hepatitis $B$ negative and positive to receive the required vaccination and treatment respectively.

\section{Abbreviations \\ Anti-HBc: Antibody to hepatitis B core antigen; Anti-HBs: Antibody to hepatitis B surface antigen; AOR: Adjusted Odds Ratio; Cl: Confidence interval; COR: Crude Odds Ratio; HBsAg: Hepatitis B surface antigen; HBV: Hepatitis B Virus; HCWS: Health Care Workers; OR: Odds Ratio; SPSS: Statistical Package for Social Sciences; UNTH: University of Nigeria Teaching Hospital}

\section{Acknowledgements}

We thank the management of University of Nigeria Teaching Hospital, Enugu. All the participants are acknowledged. We equally thank Ms. Ngozi and Ms. Ndidi who assisted in data collection and data entry.

\section{Funding \\ There was no external funding received for this study. It was completely funded by the authors.}

\section{Availability of data and materials}

All data generated and/or analysed during the study are with the corresponding author and will be available on request at any given notice.

\section{Authors' contributions}

All authors participated in and approved the study design and data collection tool. BIO participated in the designing, coordination, drafting and arranging the manuscript to the publishable level. IUN and MAI participated in data analysis and critical revision of the work for intellectual content. OO, ODO, ANC, OLC, and EOU participated in the critical revision of the paper. $\mathrm{BIO}, \mathrm{NT}$, and IUN conceived the study and designed the work and also participated in data collection and manuscript preparation. OVE, BIO, OO, ODO, ANC, OLC, and EOU participated in data acquisition, data analysis and interpretation of findings. EOU was responsible for language and technical editing/copyediting of the manuscript. All the authors read and approved the final manuscript.

\section{Ethics approval and consent to participate}

Ethical approval was obtained from Health Research Ethics Committees of the University of Nigeria Teaching Hospital, Ituku-Ozalla, Enugu. Informed written consent was obtained from the participants.

\section{Consent for publication \\ Not applicable}

\section{Competing interests}

The authors declare that they have no competing interests.

\section{Publisher's Note}

Springer Nature remains neutral with regard to jurisdictional claims in published maps and institutional affiliations.

\section{Author details}

${ }^{1}$ Department of Community Medicine, College of Medicine, University of Nigeria, Enugu Campus, Nigeria. ${ }^{2}$ Department of Medicine, College of Medicine, University of Nigeria, Enugu Campus, Nigeria. ${ }^{3}$ Department of Chemical Pathology, College of Medicine, University of Nigeria, Enugu Campus, Nigeria. ${ }^{4}$ Department of Haematology, College of Medicine, University of Nigeria, Enugu Campus, Nigeria. ${ }^{5}$ Department of Dermatology, College of Medicine, University of Nigeria, Enugu Campus, Nigeria. 
${ }^{6}$ Department of Obstetrics and Gynaecology, College of Medicine, University of Nigeria, Enugu Campus, Nigeria.

Received: 6 January 2018 Accepted: 14 June 2018

Published online: 28 June 2018

\section{References}

1. Erhabor O, Ejele OA, Nwauche CA. Epidemiology and management of occupational exposure to blood borne viral infections in a resource poor setting: the case for availability of post exposure prophylaxis. Nig J Clin Pract. 2007:10(2):100-4.

2. Bello AC. Prevalence of hepatitis B virus markers in surgeons in Lagos, Nigeria. East Afr Med J. 2000;77(5):283-5.

3. Chang MH, Hepatitis B. Virus infection. Semin Fetal Med. 2007;12:160-7.

4. Fatusi AO, Fatusi OA, Esimai AO, Onayade AA, Ojo OS. Acceptance of hepatitits $B$ vaccine by workers in a Nigerian Teaching Hospital. East Afr Med J. 2000;77:608-12.

5. WHO. Global policy report on the prevention and control of viral hepatitis in WHO member states. World Health organisation; 2013.

6. Ceters for Disease Control and Prevention. Protection against Viral hepatitis. Morb Mortal Wkly Rep. 1990;39:1.

7. Bojuwoye BJ. The burden of viral hepatitis in Africa. West Afr J Med. 1997;16:198-202.

8. Dannetum E, Tegnell A, Torner A, Giesecke J. Coverage of hepatitis B vaccination in Swedish health care workers. J Hosp Infect. 2006;63(2):201-4.

9. WHO. Hepatitis B: Key facts. World Health Organization 2016. Available: http:// www.who.int/mediacentre/factsheets/fs204/en/. Accessed 27 Nov 2017.

10. Bonani P, Bonnaccorsi G. Vaccination against hepatitis B in health care workers. Vaccione. 2001;19:2389-94.

11. Bridget $M$, Saad BO, Beatrice $M$, Trish A. Protecting health workers from nosocomial hepatitis $B$ infections: a review of strategies and challenges for implementation of hepatitis B vaccination among health workrers in subSaharan Africa. J Epidemiol Glob Health. 2017:6:229-41.

12. Runner SC, Bare B. Brunner and Suddarth's textbook of medical surgical nursing. 10th ed; 2003 .

13. Ogunbodede EO. Occupational hazard and safety in dental practice. Nigeria J Med. 1996:5:11-3.

14. Trinkoff AM, Le R, Geiger-Brown J, Lipscomb J. Work schedule, needle use, and needle stick injuries among registered nurses. Infect Control Hosp Epidemiol. 2007;28:156-64

15. Kumar A, Khuwaja AK, Khuwaja AM. Knowledge practice gaps about needle stick injuries among healthcare workers at tertiary care hospitals of Pakistan. J Ayub Med Coll Abbottabad. 2012;24(3-4):50-2.

16. Sukriti Pati NT, Sethi A, Agrawal K, et al. Low levels of awareness, coverage, and the need for boosters among health care workers in tertiary care hospitals in India. J Gastroenterol Hepatol. 2008:23(11):1710-5.

17. Gedefaw A, Muluken A. Hepatitis B vaccine knowledge and vaccination status among health care workers of Bahir Dar City Administration, Northwest Ethiopia: a cross sectional study. BMC Infect Dis. 2015;15:30-5.

18. Ademowo CA, Ajuwon A. The immunization status and level of knowledge about hepatitis B virus infection among Nigerian surgeons. West Afr J Med. 1997;16:93-6.

19. Sofola OO, Uti OG. Hepatitis B virus infection and prevention in the dental clinic: knowledge and factors determining vaccine uptake in a Nigerian dental teaching teaching hospital. Nig Q J Hosp Med. 2008:18:145-8.

20. Ibekwe RC, Ibeziakor N. Hepatitis B vaccination status among health workers in Enugu, Nigeria. Nigeria J Clin Pract. 2006;9(1):7-10.

21. Okwara EC, Enwere OZ, Diwe CK, Azike JE, Chuwulebe AE. Theatre and laboratory workers awareness of and safety practices against hepatitis B \& $C$ infection in a suburban University Teaching Hospital in Nigeria. Pan Afr Med J. 2012;2(1):45-8

22. Mueller A, Stoetter L, Kallurya S, Stich A, Majinge C, Weissbrich B, Kasang C. Prevalence of hepatitis $B$ virus infection among health care workers in a tertiary hospital in Tanzania. BM Infect Dis. 2015;15:386.

23. Singhal V, Bora D, Singh S. Prevalence of hepatitis B virus infection in healtg care workers of a tertiary care centre in India and their vaccination status. J Vaccines Vaccine. 2012;2:118

24. Abiola AO, Agunbiade AB, Badmos KB, Lesi AO, Lawal AO, Alli QO Prevalence of $\mathrm{HBs} A \mathrm{G}$, knowledge, and vaccination practice against viral hepatitis B infection among doctors and nurses in a secondary health facility in Lagos state, South-Western Nigeria. Pan Afr Med J. 2016;26:158-62.
25. Hashemi SH, Mamani M, Torabian S. Hepatitis B vaccination coverage and sharp injuries among health care workers in Hamadan, Iran. Avicenna J Clin Microbiol Inf. 2014;31(2):56-9.

26. Dannetun E, Tegnell A, Torner A, Giesecke J. Coverage of hepatitis B vaccination in Swedish health care workers. J Hosp Infect. 2006;63(2):202-6.

27. Mengal HU, Howteerrakul N, Suwannapong N, Rajatanun T. Factors relating to acceptance of hepatitis B virus vaccination by nursing students in a tertiary hospital, Pakistan. J Health Popul Nutr. 2008;26(1):46-53.

28. Burnett RJ, Francois $G$, Mphahlele MJ, et al. Hepatitis B vaccination coverage in health care workers in Gauteng Province, South Africa. Vaccine. 2001;29(25):4293-9.

29. Ogunlade LO. Perspectives on hepatitis B vaccination among Health Care Workers in Nigeria. Int J Trop Dis Health. 2016;18(3):1-11.

30. Kiire CF. The epidemiology and prophylaxis of hepatitis B in sub-Saharan Africa: a view from tropical and subtropical Africa. Gut. 1996:38(2):s5-s12.

31. Abara WE, Qaseem A, Schillie S, McMahon BJ, Harris AM, High Value Care Task Force of the American College of $\mathrm{P}$, et al. Hepatitis B vaccination, screening and linkage to care: best practice advice from the American College of Physicians and the Centers for Disease Control and Prevention. Ann Intern Med. 2017:167(11):794-804.

\section{Ready to submit your research? Choose BMC and benefit from:}

- fast, convenient online submission

- thorough peer review by experienced researchers in your field

- rapid publication on acceptance

- support for research data, including large and complex data types

- gold Open Access which fosters wider collaboration and increased citations

- maximum visibility for your research: over $100 \mathrm{M}$ website views per year

At BMC, research is always in progress.

Learn more biomedcentral.com/submissions 